\title{
The Potential for Denitrification of Ground Water by Coastal Plain Sediments in the Patuxent River Basin, Maryland
}

\author{
by L. Joseph Bachman and David E. Krantz
}

\begin{abstract}
Ithough nitrogen is essential for healthy plant and animal populations, elevated concentrations of this nutrient can degrade water quality, and excessive concentrations of nitrate (the most common form of nitrogen dissolved in streams and ground water) in surface water can trigger the growth of algae and other nuisance plants. A significant part of the total nitrogen load to Chesapeake Bay is carried by ground water that discharges to streams that flow into the Bay. Marine and estuarine silts in the Coastal Plain of Southern Maryland have a high potential to reduce the amount of nitrate in the ground water flowing through the sediments and consequently into the Bay.
\end{abstract}

\section{Delivery of Excess Nitrogen to the Chesapeake Bay}

The delivery of excess nutrients to the Chesapeake Bay (fig. 1) is one of the most serious environmental problems faced by resource managers. Although all nutrients contribute to overenrichment, the Bay ecosystem is generally "nitrogen limited," that is, excess nitrogen is the critical factor that triggers phytoplankton blooms. Much of the nitrogen load to the Bay is in the form of dissolved nitrate, which is derived from several primary sources, including atmospheric deposition, effluent from wastewater treatment plants, and fertilizer applied to agricultural fields, lawns, and golf courses. A significant percentage of the total nitrogen load to the Bay is carried by ground water that flows through the surficial (unconfined or water-table) aquifer and discharges to streams as base flow. Base flow is the part of total streamflow derived from ground-water discharge rather than from storm runoff. The average transit time for nitrate carried through the surficial aquifer in the Maryland Coastal Plain is

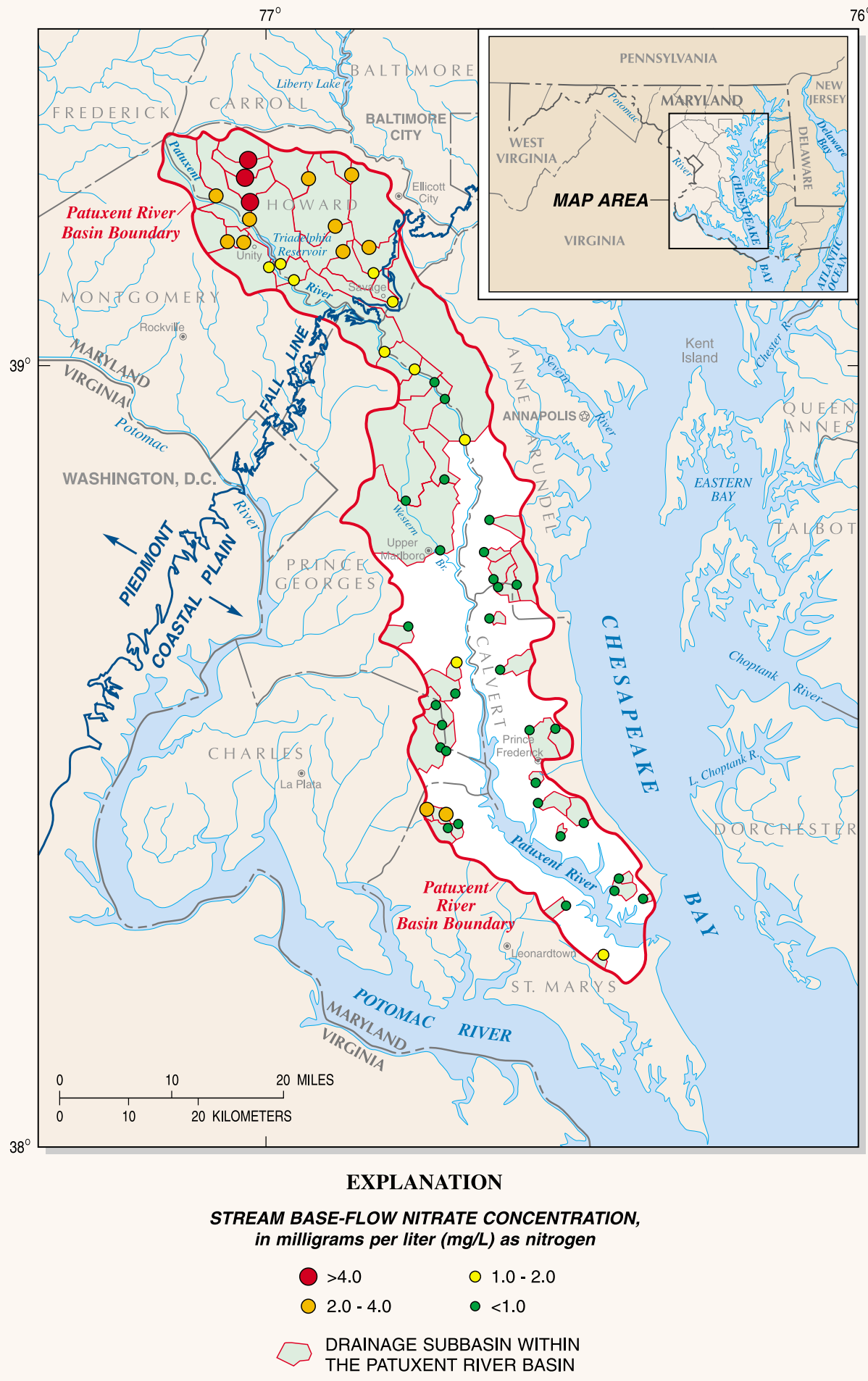

Figure 1. Location of the Patuxent River Basin and stream base-flow measurement sites in the Piedmont and Coastal Plain sections of the watershed. 
Table 1. Geologic units in the Southern Maryland Coastal Plain, their characteristics, and potential for denitrification of ground water [Derived from Coastal Plain geologic units mapped and described by Cleaves and others (1968), McCartan (1989a, 1989b), and McCartan and others (1995)]

\begin{tabular}{|c|c|c|c|}
\hline GEOLOGIC UNIT & $\begin{array}{l}\text { DEPOSITIONAL } \\
\text { ENVIRONMENT }\end{array}$ & SEDIMENT TYPE & $\begin{array}{l}\text { DENITRIFICATION } \\
\text { POTENTIAL }\end{array}$ \\
\hline $\begin{array}{l}\text { HOLOCENE ESTUARINE } \\
\text { SEDIMENTS }\end{array}$ & $\begin{array}{l}\text { FLUVIAL TO } \\
\text { ESTUARINE }\end{array}$ & $\begin{array}{c}\text { SANDY SILTS TO } \\
\text { ORGANIC-RICH MUDS } \\
\text { WITH PYRITE }\end{array}$ & HIGH \\
\hline LOWLAND DEPOSITS & ESTUARINE & $\begin{array}{l}\text { MUDDY SANDS TO } \\
\text { SANDY SILTS WITH } \\
\text { ORGANIC MATTER } \\
\text { AND PYRITE }\end{array}$ & HIGH \\
\hline UPLAND GRAVELS & FLUVIAL & $\begin{array}{l}\text { COARSE SANDS AND } \\
\text { GRAVELS, PRIMARILY } \\
\text { QUARTZ AND CHERT; } \\
\text { EXTENSIVELY } \\
\text { WEATHERED }\end{array}$ & LOW \\
\hline $\begin{array}{l}\text { CHESAPEAKE GROUP } \\
\text { (includes St. Marys, } \\
\text { Choptank, and } \\
\text { Calvert Formations) }\end{array}$ & $\begin{array}{c}\text { MARINE } \\
\text { (INNER SHELF) }\end{array}$ & $\begin{array}{l}\text { SILT TO SILTY SAND, } \\
\text { VARIABLE AMOUNTS } \\
\text { OF GLAUCONITE } \\
\text { AND PYRITE }\end{array}$ & $\begin{array}{c}\text { HIGH; } \\
\text { EXCEPT LOW FOR SANDY } \\
\text { BEDS IN THE UPPER } \\
\text { ST. MARYS AND UPPER } \\
\text { CHOPTANK FORMATIONS }\end{array}$ \\
\hline $\begin{array}{l}\text { PAMUNKEY GROUP } \\
\text { (includes Piney Point, } \\
\text { Nanjemoy, Marlboro Clay, } \\
\text { and Aquia Formations) }\end{array}$ & $\begin{array}{c}\text { MARINE } \\
\text { (INNER TO MIDDLE } \\
\text { SHELF) }\end{array}$ & $\begin{array}{l}\text { GLAUCONITIC SANDS } \\
\text { WITH INTERBEDDED } \\
\text { SILTS; PYRITE } \\
\text { COMMON IN SILT }\end{array}$ & $\begin{array}{l}\text { INTERMEDIATE } \\
\text { (MIXED) }\end{array}$ \\
\hline $\begin{array}{l}\text { MAGOTHY, MONMOUTH, } \\
\text { AND MATAWAN } \\
\text { FORMATIONS }\end{array}$ & $\begin{array}{l}\text { MARINE } \\
\text { (NEARSHORE TO } \\
\text { INNER SHELF) }\end{array}$ & $\begin{array}{l}\text { SAND AND SILTY SAND, } \\
\text { VARIABLE AMOUNTS } \\
\text { OF GLAUCONITE } \\
\text { AND PYRITE }\end{array}$ & INTERMEDIATE \\
\hline POTOMAC GROUP & FLUVIAL-DELTAIC & $\begin{array}{l}\text { SAND AND GRAVEL } \\
\text { INTERBEDDED WITH } \\
\text { SILT AND CLAY; } \\
\text { SOME PYRITE AND } \\
\text { ORGANIC MATTER }\end{array}$ & $\begin{array}{l}\text { INTERMEDIATE } \\
\text { (MIXED) }\end{array}$ \\
\hline
\end{tabular}

Explanation for Categories of Denitrification Potential

HIGH - Sediments in the surficial aquifer have abundant reduced compounds that may react chemically to decrease ground-water nitrate concentrations.

LOW - Sediments in the surficial aquifer are unreactive and will not affect ground-water nitrate concentrations.

INTERMEDIATE - Applied to geologic units with mixed and variable sediment type; individual beds may have a High denitrification potential, but the unit (as a whole) may be composed mostly of sediments with a Low denitrification potential.

estimated to be about 20 years (Focazio and others, 1998); consequently, there will be a delay between implementation of nitrogen-control practices and a measurable decrease in base-flow nitrate concentrations.

Management tools such as agricultural nutrient-control plans designed to reduce nitrogen inputs from nonpoint sources are generally applied uniformly without consideration of differences in natural setting that may mitigate or exacerbate contamination problems. Some hydrogeologic settings may enhance the removal, or natural attenuation, of nitrate from shallow ground water. Natural attenuation is the reduction in concentration of a contaminant by natural processes. The natural attenuation of groundwater nitrate may occur by plant uptake, mixing and dilution with low-nitrate water, bacterial activity, or consumption in chemical oxidation-reduction reactions (also known as "redox reactions"). An example of the latter case is denitrification, in which the oxygen atoms of the nitrate $\left(\mathrm{NO}_{3}{ }^{-}\right)$are removed by chemical reduction to produce nitrogen gas $\left(\mathrm{N}_{2}\right)$, which is effectively non-reactive.

Denitrification occurs in the absence of dissolved oxygen and in the presence of chemically reduced compounds such as organic carbon or iron sulfide minerals such as pyrite $\left(\mathrm{FeS}_{2}\right)$. Denitrification is usually mediated by bacteria, which derive energy from the reaction.

Marine and estuarine silts and clays in the Southern Maryland Coastal Plain commonly contain reduced compounds that can act as a substrate for denitrification. In contrast, marine sands and fluvial (riverine) sands and gravels typically contain little organic carbon and are composed primarily of minerals such as quartz that are generally unreactive. This Fact Sheet is based on U.S. Geological Survey Water-Resources Investigations Report 00-4051 (Krantz and Powars, in press), which evaluates the role of Coastal Plain sediments in the natural attenuation of ground-water nitrate, and presents a map of the potential for denitrification in the surficial aquifer of Southern Maryland.

\section{Measuring Nutrient Loads in the Patuxent River Basin}

The U.S. Geological Survey and the Maryland Department of Natural Resources have worked together since 1985 to measure nutrient and suspendedsediment loads from nontidal streams in the Patuxent River Basin (fig. 1). The Patuxent River Basin is the largest watershed located entirely within Maryland, and has land-use characteristics typical of the metropolitan areas in the MidAtlantic States. The Coastal Plain part of the basin is underlain by unconsolidated sediments that store and transmit a large volume of ground water. Stream base flow (from ground-water discharge) may account for 54 to 79 percent of total streamflow in the basin, and 20 to 75 percent of the total nitrogen load (Preston and Summers, 1997).

Base-flow nitrate concentrations are significantly higher in the Piedmont than in the Coastal Plain section of the Patuxent River Basin (Preston, 1996), although land use, which is related to sources of nitrate, is similar in the sampled subbasins in both sections. Further, the base-flow nitrate concentrations from the Coastal Plain sites in the Patuxent River Basin are significantly lower than those from subbasins with similar land use on the well-drained upland of the Delmarva Peninsula (Bachman and Phillips, 1996; Shedlock and others, 


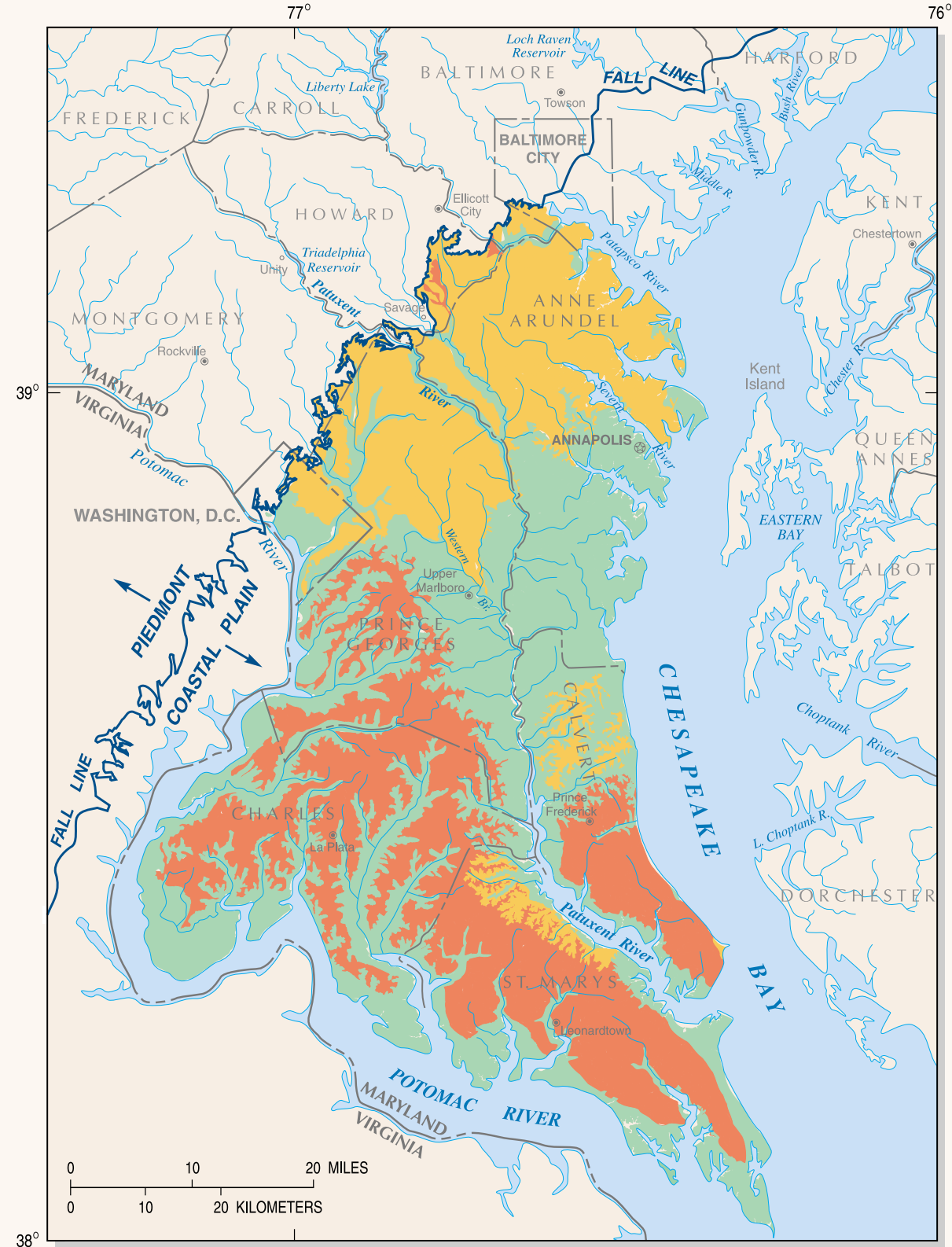

EXPLANATION

POTENTIAL FOR DENITRIFICATION IN THE SURFICIAL AQUIFER

HIGH

INTERMEDIATE

LOW

Figure 2. Potential for denitrification of ground water in the surficial aquifer, Coastal Plain of Southern Maryland.

1999). These differences may be explained in part by the hypothesis that certain geologic units in the Coastal Plain of the Patuxent River Basin have geochemical properties that may reduce nitrate concentrations in ground water. Research in other areas of the Maryland Coastal Plain (Böhlke and Denver, 1995; O'Connell and others, 1997) has provided evidence of a zone of denitrification at the base of surficial aquifers that contain sediments rich in reduced chemical species. The concentrations of dissolved (table 1) from available geologic maps and cross sections (Cleaves and others, 1968; Hansen, 1968, 1996; McCartan, 1989a, 1989b; McCartan and others, 1995). The generalized relations between geologic units, depositional environments, sediment type and texture, and the presence of reduced chemical species were used to translate the surficial geology into a map of the potential for denitrification in the Coastal Plain of Southern Maryland (fig. 2).

Marine and estuarine silts and clays with abundant pyrite, glauconite (a clay mineral with reduced iron), and/or organic carbon have a high potential for denitrification. Two examples of this sediment type are the Calvert Formation, which is exposed at the land surface over much of northern Calvert and southern Anne Arundel Counties, and the Lowland Deposits, which form a rim around the tidal tributaries (green areas in figure 2). In contrast, fluvial sands and gravels, composed of chemically resistant minerals (primarily quartz, chert, and feldspar), are very permeable and usually deeply weathered.

Consequently, these sediments have a very low potential for denitrification.

The Upland Gravels that cover a broad area in St. Marys and Charles Counties (red areas in figure 2) are an example of this type of sediment. Geologic units with variable textures and mineral composition may have denitrification occurring in one part of the formation but not elsewhere; these units are classified as having an intermediate potential for denitrification. An example is the fluvial Potomac Group along the inner margin of the Coastal Plain (orange areas in figure 2).

In this classification, a high potential for denitrification means that ground water passing through the unit will discharge with low nitrate concentrations regardless of the nitrate concentration from the source; this indicates that nitrate has been removed from the ground water. A low denitrification potential means that ground water with a high nitrate concentration will have a high nitrate concentration when it discharges as stream base flow, with little or no removal of nitrate from the ground water. Ground water with a low initial nitrate concentration, however, will yield low-nitrate discharge even if the aquifer has a low denitrification potential. For 
settings with an intermediate denitrification potential, some fraction of the total volume of ground water may undergo denitrification, and nitrate concentrations in discharging waters may be relatively low but may still exceed natural background levels (typically less than 0.1 milligram per liter as nitrogen). Areas with a low denitrification potential are the most susceptible to nitrate contamination of ground water.

The analysis and interpretation presented in figure 2 are preliminary and generalized, and have not been verified by process studies in the field. More detailed investigation may yield further insight into the relation between mapped geologic units and denitrification potential. For example, the volume of ground water discharging from each sedimentary unit has not been quantified, nor has the potential nitrate load that can be denitrified. Flow-path studies in selected geologic units would document denitrification in the surficial aquifer and provide estimates of the amount of nitrate transported by ground-water discharge.

\section{Implications for Nutrient Management}

A significant percentage of the nitrate delivered to Coastal Plain streams comes from ground water discharging to the streams as base flow. Policies designed to reduce stream nitrogen loads must consider the surficial aquifer as the conduit from sources at the land surface (such as atmospheric deposition and fertilizer application) to the streams, and as a reservoir with a holding time of 10 to 20 years. The surficial aquifer in the Coastal Plain is not a homogeneous layer of sand; it contains sediments deposited in different environments that have dramatically different chemical properties. Marine and estuarine silts commonly contain abundant organic carbon and other reduced compounds that may react to remove nitrate from ground water. Areas of the Coastal Plain underlain by sands and gravels are inherently more susceptible to nitrate contamination, whereas areas underlain by silts may have active natural attenuation of nitrate. The distribution of these reactive and non-reactive sediments can be mapped regionally and locally.

The map of potential for denitrifica- tion presented here is a first step toward identifying those areas of the Coastal Plain most susceptible to nitrate contamination. This information, although generalized, may be used by resource managers to evaluate alternative strategies for decreasing nitrogen loads to the estuarine rivers of Southern Maryland.

\section{References Cited}

Bachman, L.J., and Phillips, P.J., 1996, Hydrologic landscapes on the Delmarva Peninsula, part 2: Estimates of base-flow nitrogen load to Chesapeake Bay: Journal of the American Water Resources Association, v. 32, p. 779-791.

Böhlke, J.K., and Denver, J.M., 1995, Combined use of groundwater dating, chemical, and isotopic analyses to resolve the history and fate of nitrate contamination in two agricultural watersheds, Atlantic Coastal Plain, Maryland: Water Resources Research, v. 31, p. 2,319-2,339.

Cleaves, E.T., Edwards, J., Jr., and Glaser, J.D., 1968, Geologic map of Maryland: Maryland Geological Survey, 1 sheet, scale 1:250,000.

Focazio, M.J., Plummer, L.N., Böhlke, J.K., Busenberg, Eurybiades, Bachman, L.J., and Powars, D.S., 1998, Preliminary estimates of residence times and apparent ages of ground water in the Chesapeake Bay watershed, and water-quality data from a survey of springs: U.S. Geological Survey WaterResources Investigations Report 97-4225, $75 \mathrm{p}$.

Hansen, H.J., 1968, Geophysical $\log$ cross-section network of the Cretaceous sediments of Southern Maryland: Maryland Geological Survey Report of Investigations No. 7, 46 p.

Hansen, H.J., 1996, Hydrostratigraphic framework of the Piney PointNanjemoy aquifer and Aquia aquifer in Calvert and St. Marys Counties, Maryland: Maryland Geological Survey Open-File Report 96-02-8, 45 p.

Krantz, D.E., and Powars, D.S., in press, Hydrogeologic setting and potential for denitrification in ground water, Coastal Plain of Southern Maryland: U.S. Geological Survey Water-Resources Investigations Report 00-4051.

McCartan, Lucy, 1989a, Geologic map of Charles County: Maryland Geological Survey, 1 sheet, scale $1: 62,500$.
, 1989b, Geologic map of St. Marys County: Maryland Geological Survey, 1 sheet, scale 1:62,500.

McCartan, Lucy, Newell, W.L., Owens, J.P., and Bradford, G.M., 1995, Geologic map and cross sections of the Leonardtown 30- x 60-minute quadrangle, Maryland and Virginia: U.S. Geological Survey Open-File Report 95665, 1 sheet, scale 1:100,000.

O'Connell, M.E., Böhlke, J.K., and Prestegaard, K.L., 1997, Processes affecting the discharge of nitrate from a small agricultural watershed at different flow conditions, Maryland Coastal Plain: Eos, Transactions of the American Geophysical Union, 1997 Spring Meeting, v. 78, no. 17, p. S168.

Preston, S.D., 1996, Study of nonpoint source nutrient loading in the Patuxent River Basin, Maryland: U.S. Geological Survey Water-Resources Investigations Report 96-4273, 6 p.

Preston, S.D., and Summers, R.M., 1997, Estimation of nutrient and suspended-sediment loads in the Patuxent River Basin, Maryland, water years 198690: U.S. Geological Survey WaterResources Investigations Report 96-4175, 69 p.

Shedlock, R.J., Denver, J.M., Hayes, M.A., Hamilton, P.A., Koterba, M.T., Bachman, L.J., Phillips, P.J., and Banks, W.S.L., 1999, Water-quality assessment of the Delmarva Peninsula, Delaware, Maryland, and Virginia: Results of investigations, 1987-91: U.S. Geological Survey Water-Supply Paper 2355-A, 41 p.

\section{For further information contact:}

District Chief

U.S. Geological Survey

8987 Yellow Brick Road

Baltimore, Maryland 21237

or visit the Maryland-Delaware-D.C. District Homepage on the World Wide Web at: http://md.usgs.gov

FS-053-00

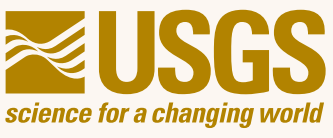

